\title{
RELATIVE EFFECTIVENESS OF CORE STABILITY EXERCISE AND MC KENZIE EXERCISE FOR PAIN RELIEF IN PATIENTS WITH LOW BACK PAIN
}

\author{
Afif Ghufroni, Ganesa Puput Dinda Kurniawan \\ Physiotherapy, School of Health Polytechnics, Ministry of Health Surakart.
}

\begin{abstract}
Background: The non-specific low back pain (LBP) is a frequent problem faced by the majority of people at some point in their lifetime. Exercise therapy has been advocated an effective treatment for chronic low back pain. This study aimed to determine the effectiveness of McKenzie's exercises and core stability exercises for pain relief in patients with LBP.

Subjects and Method: This was a randomized control trial (RCT) conducted at Dr. Soeradji Tirtonegoro Hospital, Klaten, Central Java from August to September 2017. A sample of 32 patients were randomized into two groups: 16 patients received Mc Kenzie exercise and 16 patients received core stability exercise. The independent variable was pain treatment (McKenzie exercise vs. core stability exercise). The dependent variable was non-specific LBP. LBP was measured by visual analog scale (VAS). The difference in mean reduction of non-specific LBP between the two groups was tested by independent t test.

Results: The difference in the non-specific LBP reduction after treatment in the Mc Kenzie exercise group (Mean=34.81; $\mathrm{SD}=9.61$ ) was higher than in the core stability group (Mean $=26.88 ; \mathrm{SD}=7.60)$ and it was statistically significant $(\mathrm{p}=0.015)$.

Conclusion: The Mc Kenzie exercise is more effective than core stability exercise to reduce non-specific low back pain.
\end{abstract}

Keywords: non-spesific low back pain, core stability exercise, Mc Kenzie exercise.

Correspondence:

Afif Ghufroni. Physiotherapy, School of Health Polytechnics, Ministry of Health Surakarta, Surakarta, Central Java. Email: apip.physio@gmail.com.

Mobile: 085725000769.

The 5th International Conference on Public Health

Best Western Premier Hotel, Solo, Indonesia, February 13-14, 2019 | 675

https://doi.org/10.26911/theicph.2019.05.31 